\title{
Aktif İçeriği Sodyum Dimetilditiyokarbamat Olan Antimikrobiyal Maddenin Antibiyotiklere Dirençli Referans Bakteri Suşlarına Karşı Minimum İnhibitör Konsantrasyonlarının Araştırılması
}

\author{
Investigation of Minimum Inhibitor Concentrations of Antimicrobial Agent with Active \\ Ingredient Sodium Dimethyldithiocarbamate against Antibiotic Resistant Reference Bacterial \\ Strains
}

\author{
Pınar ÇAĞLAYAN ${ }^{1}$ \\ ${ }^{1}$ Marmara Üniversitesi, Fen Edebiyat Fakültesi, Biyoloji Bölümü, 34722, İstanbul, Türkiye
}

Öz

Tuzlanmış deriler, kaybettiği suyun geri kazandırılarak yeniden yumuşaması ve üzerindeki tuzun, dışkının, mikroorganizmaların temizlenmesi amacıyla 1slatma işlemine sokulmaktadır. Deri endüstrisinde sslatma işleminin içerdiği organik yük sebebiyle bakteriler gelişebilmektedir. Bakteriyel gelişmenin deride önemli zararlara sebep olduğu bilinmektedir. Islatma işleminde çeşitli antimikrobiyal maddeler kullanılmasına rağmen, sslatma sıvılarında ve sslatılmış derilerde antibiyotiklere dirençli Gram-pozitif ve Gram-negatif bakteriler daha önceki çalışmalarda saptanmıştır. Islatma işleminin verimli ve etkili bir biçimde yapılabilmesi için antimikrobiyal maddenin uygun miktarda kullanılması oldukça önemlidir. Böylece, derilerde bakteri kaynaklı zararlar kontrol altına alınabilecektir. Bu çalışmada, Gram-negatif ve Gram-pozitif referans bakteri suşlarııı farklı antibiyotiklere karşı duyarlılıkları Kirby-Bauer disk difüzyon metodu ile araştırılmıştır. Ayrıca, sslatma işleminde kullanılan aktif içeriği sodyum dimetilditiyokarbamat olan antimikrobiyal maddenin farklı konsantrasyonları bu bakterilere ve bunların karışık kültürü üzerine uygulanarak minimum inhibisyon konsantrasyonu agar dilüsyon metoduyla araştırılmıştır. Test bakterileri ampisilin $(10 \mu \mathrm{g})$, spektinomisin $(25 \mu \mathrm{g})$, streptomisin $(10 \mu \mathrm{g})$, meropenem $(10 \mu \mathrm{g})$ ve penisilin $(10 \mathrm{U})$ antibiyotiklerine karşı dirençli bulunmuştur. Antimikrobiyal maddenin minimum inhibisyon konsantrasyon değerleri Pseudomonas aeruginosa ATCC27853, Staphylococcus aureus ATCC29213, Micrococcus luteus ATCC9341, ve tüm test bakterilerinin karışık kültürü için 1000 $\mu \mathrm{g} / \mathrm{ml}$; Escherichia coli ATCC25922 ve Bacillus cereus ATCC11778 için $500 \mu \mathrm{g} / \mathrm{ml}$; Staphylococcus epidermidis ATCC12228 ve Enterococcus faecalis ATCC29212 için $15.6 \mu \mathrm{g} / \mathrm{ml}$; ve Bacillus subtilis ATCC6633 için ise $3.9 \mu \mathrm{g} / \mathrm{ml}$ olarak saptanmıştı. Bu çalışmadan elde edilen verilere göre, antibiyotiklere dirençli sekiz farklı referans bakteri suşunun ve bunların karışık kültürünün gelişimleri test edilen antimikrobiyal madde ile inhibe edildiği belirlenmiştir.

Anahtar kelimeler: Gram-pozitif bakteri, Gram-negatif bakteri, Kirby-Bauer disk difüzyon metodu, Antibiyotik direnci, Antibakteriyel madde, Minimum inhibisyon konsantrasyonu, agar dilüsyon metodu

\begin{abstract}
The leather industry is an important commercial sector for the global economy. The hides and skins are contaminated with microorganisms found in air, soil, water, feces and slaughterhouse. After the animal is flayed, the hide and skin provide an ideal growth condition for these microorganisms due to containing fat and protein. Different chemical agents such as sodium chloride, boric acid, antifungal and antibacterial agents are used to preserve raw hides and skins in order to prevent microbial growth and damage on hides and skins during transportation and storage period. The salted hides are soaked in soaking process in order to re-soften and removing the salt, feces and microorganisms on the hide surface. Bacteria can develop in the leather industry due to the organic load in the soaking process. Bacterial growth is known to cause significant damage to the hides and skins such as discoloration, bad odor, hair slip, grain peeling, fiber disintegration, weakness, looseness and holes. Although various antimicrobial agents have been used in the soaking process, Gram-positive and Gram-negative bacteria resistant to antibiotics in soaking liquids and soaked hides have been identified in previous studies. It is very important to use the antimicrobial
\end{abstract}


agent in the proper amount so that the soaking process can be carried out efficiently and effectively. Thus, bacterial damage can be controlled in the skin. Hence, the aim of the present study was to investigate the susceptibilities of Gram-negative (Pseudomonas aeruginosa ATCC 27853, Escherichia coli ATCC 25922) and Gram-positive (Staphylococcus epidermidis ATCC 12228, Staphylococcus aureus ATCC 29213, Micrococcus luteus ATCC 9341, Enterococcus faecalis ATCC 29212, Bacillus cereus ATCC 11778, Bacillus subtilis ATCC 6633) reference bacterial strains to five different antibiotics (ampicillin, spectinomycin, streptomycin, meropenem and penicillin) by Kirby-Bauer disc diffusion susceptibility test method on Mueller Hinton Agar. In addition, 18 different concentrations of the antimicrobial agent $(4000 \mu \mathrm{g} / \mathrm{ml}, 2000 \mu \mathrm{g} / \mathrm{ml}, 1000 \mu \mathrm{g} / \mathrm{ml}, 500 \mu \mathrm{g} /$ $\mathrm{ml}, 250 \mu \mathrm{g} / \mathrm{ml}, 125 \mu \mathrm{g} / \mathrm{ml}, 62.5 \mu \mathrm{g} / \mathrm{ml}, 31.2 \mu \mathrm{g} / \mathrm{ml}, 15.6 \mu \mathrm{g} / \mathrm{ml}, 7.8$ $\mu \mathrm{g} / \mathrm{ml}, 3.9 \mu \mathrm{g} / \mathrm{ml}, 1.96 \mu \mathrm{g} / \mathrm{ml}, 0.98 \mu \mathrm{g} / \mathrm{ml}, 0.49 \mu \mathrm{g} / \mathrm{ml}, 0.24 \mu \mathrm{g} / \mathrm{ml}$, $0.12 \mu \mathrm{g} / \mathrm{ml}, 0.06 \mu \mathrm{g} / \mathrm{ml}$ and $0.03 \mu \mathrm{g} / \mathrm{ml}$ ), containing sodium dimethyldithiocarbamate as the active ingredient and used in the soaking process, were applied to these bacteria and their mixed culture and the minimum inhibitory concentration was investigated by agar dilution method. The series of two-fold dilutions of the test agent, ranging from $4000 \mu \mathrm{g} / \mathrm{ml}$ to $0.03 \mu \mathrm{g} / \mathrm{ml}$, were prepared in Mueller Hinton Agar. The test strains were grown on Mueller Hinton Agar at 37 ${ }^{\circ} \mathrm{C}$ for 24 hours. Then, overnight cultures of the test strains were inoculated into $10 \mathrm{ml}$ Mueller Hinton Broth with 2 colonies of each test strain. Each bacterial suspension was adjusted to a McFarland standard $0.5\left(10^{8}\right.$ colony forming units per $\left.\mathrm{ml}\right)$. The broth cultures of test strains were incubated at $37^{\circ} \mathrm{C}$ for 24 hours. Later, each suspension of test strain was diluted to $10^{7}$ colony forming units per $\mathrm{ml}$ using physiological saline water containing $0.85 \%$ sodium chloride. The mixed culture of the test strains was also prepared from these dilutions. An inoculum of $10^{4}$ colony forming units per $\mathrm{ml}(1$ $\mu 1)$ of each bacterial test strain and their mixed culture was separately transferred to Mueller Hinton Agar plates containing eighteen different concentrations of the antimicrobial agent. The inoculated plates were incubated at $37^{\circ} \mathrm{C}$ for 24 hours and the minimum inhibitor concentrations of antimicrobial agent against the test bacteria were determined. According to experimental results, the test bacteria were found to be resistant to ampicillin $(10 \mu \mathrm{g})$, spectinomycin $(25 \mu \mathrm{g})$, streptomycin $(10 \mu \mathrm{g})$, meropenem $(10 \mu \mathrm{g})$ and penicillin (10 U) antibiotics. The minimum inhibitor concentrations of antimicrobial agent were found as $1000 \mu \mathrm{g} / \mathrm{ml}$ for Pseudomonas aeruginosa ATCC 27853, Staphylococcus aureus ATCC 29213, Micrococcus luteus ATCC 9341, mixed culture of test bacteria; $500 \mu \mathrm{g} / \mathrm{ml}$ for Escherichia coli ATCC 25922 and Bacillus cereus ATCC 11778; $15.6 \mu \mathrm{g} / \mathrm{ml}$ for Staphylococcus epidermidis ATCC 12228 and Enterococcus faecalis ATCC 29212; and $3.9 \mu \mathrm{g} / \mathrm{ml}$ for Bacillus subtilis ATCC 6633. According to the data obtained from this study, the growths of eight different ATCC reference bacterial strains resistant to antibiotics and their mixed culture were inhibited by the tested antimicrobial agent. It is known that bacterial cells are capable of surviving and growing in the presence of antibacterial agents. Hence, it is generally difficult to control the mixture of different bacterial species with antibacterial agents. In the present study, the mixed culture of eight different ATCC reference bacterial strains were be controlled at $1000 \mu \mathrm{g} / \mathrm{ml}$ concentration of antimicrobial agent. As a result, the use of effective antimicrobial agents at the appropriate concentration in the soaking process is of great importance for the prevention of the development of antibiotic resistant bacteria found in this process and for the production of high quality leather.

Keywords: Gram-positive bacteria, Gram-negative bacteria, Kirby-Bauer Disk Diffusion Method, antibiotic resistance, antibacterial agent, minimum inhibition concentration, agar dilution method

\section{GİRIŞ}

Deri endüstrisi dünya ekonomisinde önemli bir yere sahiptir. Türkiye'de de dericilik sektörü son yıllarda ilerleyerek ülkemizin önemli endüstrileri arasında yerini almıştır. Derilerin tuz, toprak, yem, gübre, hava, su ve ahır gibi çevresel kaynaklardan bulaşan halofil olmayan, halotolerant, zayif halofil, 1lımlı halofil bakterileri, aşırı halofil arkeleri, farklı mantar ve maya türlerini içerdiği bilinmektedir. Deride bulunan bu mikroorganizmalar, nihai deri ürünlerinin kalitesi için son derece önemlidir. Bu mikroorganizmalar tarafından üretilen hidrolitik enzimler, deride kötü koku oluşumuna, kıl gevşekliğine, sırça zararına neden olmaktadır [1,2]. Derilerin dünya çapındaki ekonomik önemi nedeniyle, bu zararlı mikroorganizmaların gelişimlerinin kontrol altına alınması gerekmektedir [3]. Hayvan kesildikten sonra elde edilen ham deriye ilk olarak tuzla koruma yöntemi uygulanarak deriler depolanmaktadır. Tuzlanmış hayvan derilerine, işlenmeden hemen önce kaybettikleri nemin geri kazandırılması için ıslatma işlemi uygulanmaktadır. Deri endüstrisinde bu aşamada bakterilerin gelişiminin ve zararlarının önlenmesi amacıyla antimikrobiyal maddeler tuzlanmış ve ıslatılmış derilere yaygınca uygulanmaktadır [4]. Bu antimikrobiyal maddelerin tuzlanmış derilerde ve ıslatılmış derilerde yaygınca ve rastgele kullanımı sonucunda antimikrobiyal maddelere karşı dirençli bakterilerin ortaya çıktığı bildirilmiştir [5-8].

Dünya Sağlık Örgütü’nün 2016 yılındaki küresel raporuna göre, hastalığa neden olan mikroorganizmalara karş1 antimikrobiyal direnç hemen hemen her ülkede ve birçok sektörde dramatik bir şekilde artmıştır [9]. Bu çalışmada test edilen antibiyotiklerin (streptomisin, penisilin, ampisilin, meropenem, spektinomisin) Dünya Sağlık Örgütü’nün listesinde insan ve hayvan hastalıklarının tedavisinde kullanıldığı belirtilmiştir [9]. İnsanlarda, hayvanlarda ve tarımda antibiyotiklerin aşırı kullanımı ve bilinçsiz kullanılması antibiyotiğe dirençli bakterilerin gelişimini desteklemektedir. 2011 yılında yapılan bir çalışmada antibiyotikli yemlerle beslenen hayvanların sindirim kanalında ve sütlerinde, bu sütlerden yapılan süt ürünlerinde antibiyotiklere dirençli 
Enterobacteriaceae familyası üyelerinin bulunduğu bildirilmiştir [10].

$\mathrm{Bu}$ çalışmada kullanılan tüm test bakterileri deri endüstrisinden izole edilerek tanımlanmıştır. Örneğin, B. subtilis, $B$. cereus, M. luteus, S. aureus, P. aeruginosa, S. epidermidis deri endüstrisindeki farklı işlenti basamaklarından izole edilerek tanımlanmıştır [11]. Bu izolatların proteaz enzimini üreterek deride hasar oluşturduğu bildirilmiştir [11]. Yapılan diğer çalışmalarda, E. faecalis keçi derisinden [12], S. aureus keçilerden [13], P. aeruginosa ve $S$. epidermidis tuzlanmış sığır derilerinden [14,15], E. coli sığır ve koyun derilerinden [16] izole edilmiştir. Bacillus, Clostridium, Proteus, Escherichia, Micrococcus, Pseudomonas, Staphylococcus, Sarcina türlerinin de taze ve yaş derilerde, tuzlanmış derilerde, ıslatma, kıl giderme, samalama gibi işlenti basamaklarından geçmiş derilerde saptanmıştır [17]. Bu mikroorganizmaların kokuşmaya, jelatinin ve yağın sindirimine neden olduğu da belirtilmiştir.

Çeşitli Gram-pozitif ve Gram-negatif bakteri türlerinin tuzlanmış ve ıslatılmış hayvan derilerinden izole edildiği daha önce yapılan araştırmalarda bildirilmiştir [8,10-22]. Kaliteli deri üretimi deri endüstrisi açısından önem taşıması sebebiyle, bu çalışmada deri sektöründe kullanılan sodyum dimetilditiyokarbamat içeren antimikrobiyal maddenin farklı konsantrasyonları, insan ve hayvan hastalıklarının tedavisinde kullanılan antibiyotiklere karşı dirençli referans bakteri suşlarına ve bunların karışık kültürüne karşı uygulanmıştır. Test antimikrobiyali referans bakteri suşlarına ve bu suşların karışı kültürüne karşı ayrı ayrı uygulanarak minimum inhibisyon konsantrasyonu araştırılmıştır. Bu çalışmadan elde edilen veriler ışığında, derilerin işlenmesi sırasında derinin yapısında hasara neden olabilecek Gram-pozitif ve Gram-negatif bakterilerin inhibe edilebileceği en uygun konsantrasyonun belirlenmesiyle gereksiz veya yetersiz kimyasal kullanımının önlenmesi sağlanacaktır. Ayrıca, bu çalışmadan elde edilen veriler, daha önce deri endüstrisinden izole edilen ve bu çalışmadaki ATCC test suşları ile aynı tür olan bakterilerin gelişimlerinin kontrol edilmesi, derinin yapısına verebilecekleri zararın önlenmesi açısından önemlidir.

\section{MATERYAL VE METOT}

\subsection{Referans Bakteri Suşlarının Farklı Antibiyotiklere Karşı Duyarlılıklarının Araştırılması}

Test bakterilerine ait saf koloniler ayrı ayrı Mueller Hinton Broth besiyeri içeren tüplere ekilerek $37^{\circ} \mathrm{C}$ sıcaklıkta 24 saat boyunca etüvde inkübasyona bırakılmıştır. İnkübasyon süresi sonunda, her bir test suşunun yoğunluğu $10^{8} \mathrm{kob} / \mathrm{ml}(0.5$ No'lu McFarland) olacak şekilde \%0.85'lik fizyolojik tuzlu suda ayarlanmıştır. Saf koloni solüsyonları ayrı ayrı eküvyon çubuk ile Mueller Hinton Agar besiyerine homojen bir şekilde plağa yayma yöntemi ile ekilmiş̧ir. Ampisilin $(10 \mu \mathrm{g})$, spektinomisin $(25 \mu \mathrm{g})$, streptomisin $(10 \mu \mathrm{g})$, meropenem $(10 \mu \mathrm{g})$ ve penisilin (10 U) (Oxoid) antibiyotik disklerinin yerleştirildiği petri kutuları $37^{\circ} \mathrm{C}$ sicaklıkta 24 saat boyunca etüvde bekletilmiştir [23]. İnkübasyondan sonra, antibiyotik disklerinin etrafındaki inhibisyon zonları (mm) ölçülmüştür [24-25].

\subsection{Nolu McFarland Bulanıklık Standardının Hazırlanması}

$0.18 \mathrm{M}^{\prime}$ 'l $1 \mathrm{k} \mathrm{H}_{2} \mathrm{SO}_{4}$ 'ten $9.9 \mathrm{ml}$ alınarak, $0.1 \mathrm{ml} 0.048 \mathrm{M}$ 'lık $\mathrm{BaCl}_{2}$ ile karıştırılmıştır [26].

\subsection{5 Nolu McFarland Bulanıklık Standardının Hazırlanması}

1 Nolu McFarland bulanık tüpünden $5 \mathrm{ml}$ alınarak üzerine $5 \mathrm{ml}$ distile su eklenmiştir [26].

\section{4 \%0.85 NaCl İçeren Nutrient Agar Besiyerinin Hazırlanması}

$8.5 \mathrm{~g} \mathrm{NaCl}$ ve $20 \mathrm{~g}$ Nutrient Agar tartılarak, üzerine 1000 $\mathrm{ml}$ distile su ilave edilmiştir. Besiyerinin $\mathrm{pH}^{\prime} 1$ 7'ye ayarlandıktan sonra $121^{\circ} \mathrm{C}^{\prime}$ de 20 dakika otoklavda steril edilmiştir.

\subsection{Mueller Hinton Agar Besiyerinin Hazırlanması}

34 g Mueller Hinton Agar tartılarak, üzerine $1000 \mathrm{ml}$ distile su ilave edilmiştir. Besiyerinin pH'ı 7'ye ayarlandıktan sonra $121^{\circ} \mathrm{C}^{\prime}$ de 20 dakika otoklavda steril edilmiştir.

\subsection{Sodyum dimetilditiyokarbamat İçeren \\ Antimikrobiyal Maddenin Farklı Konsantrasyonlarının Referans Bakteri Suşlarına Karşı Minimum İnhibitör Konsantrasyonlarının Araştırılması}

Bu çalışmada aktif içeriği sodyum dimetilditiyokarbamat $(\% 40)$ olan ve derilerin islatılması işlemlerinde kullanılan antimikrobiyal maddenin sekiz farklı ATCC referans suşlarını ve bunların karışık kültürünü inhibe ettiği Minimum İnhibisyon Konsantrasyon (MİK) değeri agar dilüsyon yöntemiyle incelenmiştir [27,28]. Bu antimikrobiyal maddenin 18 farklı konsantrasyonu $(4000 \mu \mathrm{g} / \mathrm{ml}, 2000 \mu \mathrm{g} / \mathrm{ml}$, $1000 \mu \mathrm{g} / \mathrm{ml}, 500 \mu \mathrm{g} / \mathrm{ml}, 250 \mu \mathrm{g} / \mathrm{ml}, 125 \mu \mathrm{g} / \mathrm{ml}, 62.5 \mu \mathrm{g} / \mathrm{ml}$, $31.2 \mu \mathrm{g} / \mathrm{ml}, 15.6 \mu \mathrm{g} / \mathrm{ml}, 7.8 \mu \mathrm{g} / \mathrm{ml}, 3.9 \mu \mathrm{g} / \mathrm{ml}, 1.96 \mu \mathrm{g} / \mathrm{ml}$, $0.98 \mu \mathrm{g} / \mathrm{ml}, 0.49 \mu \mathrm{g} / \mathrm{ml}, 0.24 \mu \mathrm{g} / \mathrm{ml}, 0.12 \mu \mathrm{g} / \mathrm{ml}, 0.06 \mu \mathrm{g} / \mathrm{ml}$ ve $0.03 \mu \mathrm{g} / \mathrm{ml}$ ) hazırlanarak $19 \mathrm{ml}$ agarlı Nutrient besiyerine Tablo 1'de gösterildiği şekilde ilave edilmiştir. 
Tablo 1. Farklı konsantrasyondaki antimikrobiyal maddenin hazırlanması

\begin{tabular}{|c|c|c|c|c|c|}
\hline $\begin{array}{l}\text { İlk konsantrasyon } \\
\qquad(\mu \mathrm{g} / \mathrm{ml})\end{array}$ & $\begin{array}{r}\text { Stok } \\
(\mathrm{ml})\end{array}$ & $\begin{array}{r}\text { Distile } \\
\mathrm{su}(\mathrm{ml})\end{array}$ & $\begin{array}{c}19 \mathrm{ml} \text { besiyerinin ilavesinden } \\
\text { önceki konsantantrasyon } \\
(\mu \mathrm{g} / \mathrm{ml})\end{array}$ & $\begin{array}{l}19 \mathrm{ml} \text { besiyerinin, } 1 \mathrm{ml} \text { antimikro- } \\
\text { biyal maddenin üzerine ilavesinden } \\
\text { sonraki konsantrasyon }(\mu \mathrm{g} / \mathrm{ml})\end{array}$ & $\begin{array}{l}19 \mathrm{ml} \text { besiyerinin, } 1 \mathrm{ml} \\
\text { antimikrobiyal maddenin } \\
\text { üzerine ilavesinden sonra son } \\
\text { konsantrasyonx } 0.4(\mu \mathrm{g} / \mathrm{ml})\end{array}$ \\
\hline 200.000 & 2 & 0 & 200.000 & 10.000 & 4000 \\
\hline 200.000 & 2 & 2 & 100.000 & 5000 & 2000 \\
\hline 200.000 & 1 & 3 & 50.000 & 2500 & 1000 \\
\hline 50.000 & 2 & 2 & 25.000 & 1250 & 500 \\
\hline 50.000 & 1 & 3 & 12.500 & 625 & 250 \\
\hline 50.000 & 1 & 7 & 6250 & 312 & 125 \\
\hline 6250 & 2 & 2 & 3125 & 156 & 62.5 \\
\hline 6250 & 1 & 3 & 1562.5 & 78 & 31.2 \\
\hline 6250 & 1 & 7 & 781.25 & 39 & 15.6 \\
\hline 781.25 & 2 & 2 & 390.63 & 19.5 & 7.8 \\
\hline 781.25 & 1 & 3 & 195.31 & 9.76 & 3.9 \\
\hline 781.25 & 1 & 7 & 97.66 & 4.88 & 1.96 \\
\hline 97.66 & 2 & 2 & 48.83 & 2.44 & 0.98 \\
\hline 97.66 & 1 & 3 & 24.41 & 1.22 & 0.49 \\
\hline 97.66 & 1 & 7 & 12.21 & 0.6 & 0.24 \\
\hline 12.21 & 2 & 2 & 6.10 & 0.3 & 0.12 \\
\hline 12.21 & 1 & 3 & 3.05 & 0.15 & 0.06 \\
\hline 12.21 & 1 & 7 & 1.53 & 0.07 & 0.03 \\
\hline
\end{tabular}

\subsection{Antimikrobiyal Maddenin Stok Solüsyonunun Hazırlanması}

Aktif içeriği sodyum dimetilditiyokarbamat olan antimikrobiyal maddeden $200.000 \mathrm{mg}$ tartilarak $1000 \mathrm{ml}$ steril distile su ile karıştırılmıştır.

\subsection{Antimikrobiyal Maddenin 18 Farklı Konsantrasyonunun Hazırlanması}

Stok solüsyon hazırlandiktan sonra, Tablo 1'de belirtilen oranlarda distile su ile karıştırılmıştır. Steril 19 ml Nutrient Agar besiyeri içeren erlen mayerlere, otoklavlama işleminden sonra steril şartlarda 18 farklı antimikrobiyal madde konsantrasyonundan ayrı ayrı $1 \mathrm{ml}$ eklenmiştir. Antimikrobiyal madde $\% 40$ oranında sodyum dimetilditiyokarbamat içerdiği için son konsantrasyon 0.4 ile çarpılarak hesaplanmıştır. Her bir petri kabına toplam $20 \mathrm{ml}$ besiyeri ve antimikrobiyal madde karışımı dökülmüştür [27,29].

Gram-negatif (Pseudomonas aeruginosa ATCC27853, Escherichia coli ATCC25922) ve Gram-pozitif (Staphylococcus epidermidis ATCC12228, Staphylococcus aureus ATCC29213, Micrococcus luteus ATCC9341, Enterococcus faecalis ATCC29212, Bacillus cereus ATCC11778, Bacillus subtilis ATCC6633) referans suşlarına ait saf kolonilerden ayrı ayrı alınarak Nutrient Agar besiyerine çizgi yöntemiyle ekilmiştir. Ekimi yapılan petri kutuları sıcaklığı $37^{\circ} \mathrm{C}$ 'ye ayarlanmış etüvde 24 saatlik inkübasyona bırakılmıştır. İnkübasyon süresi sonunda koloni oluşturma biriminin (kob) hesaplanabilmesi için her bir suşun bulanıklığı 0.5 McFarland bulanıklık tüpüne göre $\left(10^{8} \mathrm{kob} / \mathrm{ml}\right)$ ayrı ayrı ayarlanmıştır. Her bir referans bakterinin süspansiyonlarından $\left(10^{8}\right.$ $\mathrm{kob} / \mathrm{ml}) 1 \mathrm{ml}$ alınarak, üzerine $9 \mathrm{ml}$ steril fizyolojik tuzlu su $(\% 0.85 \mathrm{NaCl})$ eklenmiştir. Böylece, toplam bakteri yoğunluğu her bir suş için $10^{7} \mathrm{kob} / \mathrm{ml}$ olmuştur. Karışık kültür hazırlamak için, ayrı ayrı hazırlanan bu bakteri solüsyonlarından $1 \mathrm{ml}$ alınarak steril bir tüpte karıştırılmıştır. Bakterilerin karışık kültürünün yoğunluğuda $10^{7} \mathrm{kob} / \mathrm{ml}$ olarak hazırlanmıştır [27,29]. Toplam bakteri yoğunluğu $10^{7} \mathrm{kob} / \mathrm{ml}$ olan solüsyonlardan ayrı ayrı $1 \mu$ l alınarak $\left(10^{4} \mathrm{kob} /\right.$ damla $)$ petrideki agarlı Nutrient besiyerine damla şeklinde konulmuştur. Ekimi yapılan petri kutuları $37^{\circ} \mathrm{C}$ 'lik etüvde 24 saat inkübasyona bırakılmıştır. İnkübasyon süresi sonunda üremenin görüldüğü ve görülmediği test antimikrobiyalinin konsantrasyon değerleri not edilmiştir. Bakteriyel üremenin görülmediği en düşük konsantrasyon MİK değeri olarak belirlenmiştir [27].

\section{ARAŞTIRMA SONUÇLARI}

$\mathrm{Bu}$ çalışmada kullanılan referans bakteri suşları test edilen tüm antibiyotiklere [ampisilin $(10 \mu \mathrm{g})$, spektinomisin $(25 \mu \mathrm{g})$, streptomisin $(10 \mu \mathrm{g})$, meropenem $(10 \mu \mathrm{g})$, penisilin (10 U)] karşı dirençli bulunmuştur. Sodyum 
dimetilditiyokarbamat içeren antimikrobiyal maddenin 18 farklı konsantrasyonunun referans bakterilere uygulanmastyla elde edilen sonuçlara göre, Pseudomonas aeruginosa ATCC27853, Staphylococcus aureus ATCC29213 ve Micrococcus luteus ATCC9341 suşlarını inhibe ettiği en düşük konsantrasyon değeri $1000 \mu \mathrm{g} / \mathrm{ml}$ olarak tespit edilmiştir. MIK değeri Escherichia coli ATCC25922 ve Bacillus cereus ATCC 11778 için $500 \mu \mathrm{g} / \mathrm{ml}$ olarak bulunmuşken, Staphylococcus epidermidis ATCC12228 ve Enterococcus faecalis ATCC29212 için $15.6 \mu \mathrm{g} / \mathrm{ml}$ olarak saptanmıştır. Bacillus subtilis ATCC6633 için MIK değeri $3.9 \mu \mathrm{g} / \mathrm{ml}$ olarak bulunmuştur (Tablo 2). Test antimikrobiyalinin onsekiz farklı konsantrasyonu sekiz adet ATCC referans suşun karşık kültürü üzerine uygulandığında MİK değeri $1000 \mu \mathrm{g} / \mathrm{ml}$ olarak tespit edilmiştir (Tablo 2).

Tablo 2. Aktif İçeriği Sodyum dimetilditiyokarbamat olan antimikrobiyal maddenin farklı konsantrasyonlarının ATCC referans bakteri suşlarına karşı minimum inhibitör konsantrasyonlarının sonuçları

\begin{tabular}{|c|c|c|c|c|c|c|c|c|c|c|}
\hline & 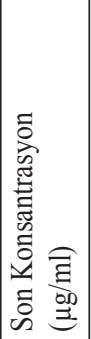 & 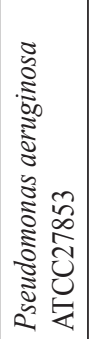 & 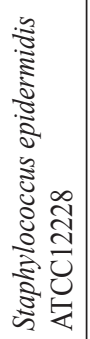 & 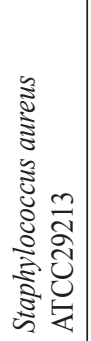 & 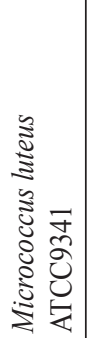 & 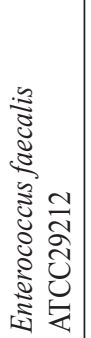 & 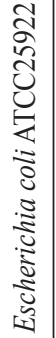 & 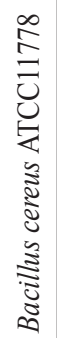 & 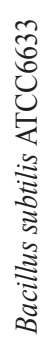 & 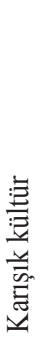 \\
\hline 1 & 4000 & - & - & - & - & - & - & - & - & - \\
\hline 2 & 2000 & - & - & - & - & - & - & - & - & - \\
\hline 3 & 1000 & - & - & - & - & - & - & - & - & - \\
\hline 4 & 500 & + & - & + & + & - & - & - & - & + \\
\hline 5 & 250 & + & - & + & + & - & + & + & - & + \\
\hline 6 & 125 & + & - & + & + & - & + & + & - & + \\
\hline 7 & 62.5 & + & - & + & + & - & + & + & - & + \\
\hline 8 & 31.2 & + & - & + & + & - & + & + & - & + \\
\hline 9 & 15.6 & + & - & + & + & - & + & + & - & + \\
\hline 10 & 7.8 & + & + & + & + & + & + & + & - & + \\
\hline 11 & 3.9 & + & + & + & + & + & + & + & - & + \\
\hline 12 & 1.96 & + & + & + & + & + & + & + & + & + \\
\hline 13 & 0.98 & + & + & + & + & + & + & + & + & + \\
\hline 14 & 0.49 & + & + & + & + & + & + & + & + & + \\
\hline 15 & 0.24 & + & + & + & + & + & + & + & + & + \\
\hline 16 & 0.12 & + & + & + & + & + & + & + & + & + \\
\hline 17 & 0.06 & + & + & + & + & + & + & + & + & + \\
\hline 18 & 0.03 & + & + & + & + & + & + & + & + & + \\
\hline
\end{tabular}

\section{TARTIŞMA VE SONUÇ}

Islatma sıvılarında yapılan araştırmalarda Bacillus, Micrococcus, Pseudomonas ve Staphylococcus cinslerine ait olan bakterilerin varlığı araştırmacılar tarafından bildirilmiştir [30-34]. Yapılan diğer bir çalışmada, \%0.4 ticari bakterisit ile 1slatılmış koyun derilerinde proteolitik, lipolitik ve sporlu bakterilerin bulunduğu bildirilmiştir [35]. Aktif içeriği didesildimetilamonyum klorür olan bir antimikrobiyal maddenin islatma sivılarında $0.4 \mathrm{~g} / \mathrm{l}^{\prime}$ lik konsantrasyonda uygulandığı bir tabakhaneden alınan ıslatma sıvısı örneklerinde proteolitik ve lipolitik bakteri sayıları sırasıyla $10^{4}-10^{7} \mathrm{kob} / \mathrm{ml}$ ve $10^{2}-10^{6} \mathrm{kob} / \mathrm{ml}$ arasında bulunmuştur [5]. Bu tabakhanelerde önerilen $0.4 \mathrm{~g} / \mathrm{l}^{\prime}$ lik kullanım konsantrasyonu iki katına $(0.8 \mathrm{~g} / \mathrm{l})$ çıkarılmasına rağmen ıslatma sıvısı örneklerinde proteolitik $\left(10^{3} \mathrm{kob} / \mathrm{ml}\right)$ ve lipolitik $\left(10^{3}\right.$ $10^{4} \mathrm{kob} / \mathrm{ml}$ ) bakteriler bulunmuştur [5]. Bu islatma sivis1 örneklerinden Bacillus mycoides, Bacillus lentus, Bacillus amyloliquefaciens, Enterobacter gergoviae, Enterobacter sakazakii, Enterobacter amnigenus biogrup I, Enterobacter cloacae, Pseudomonas fluorescens, Pseudomonas luteola, Enterococcus avium, Lactococcus lactis ssp. lactis, Enterococcus faecium, Aerococcus viridans, Vibrio parahaemolyticus, Pseudomonas putida, Staphylococcus hominis, Staphylococcus capitis, Staphylococcus sciuri, Staphylococcus xylosus, Staphylococcus cohnii ssp. urealyticus, Staphylococcus epidermidis, Kocuria varians, Staphylococcus intermedius, Staphylococcus haemolyticus, Staphylococcus lugdunensis, Staphylococcus cohnii ssp. cohnii, Staphylococcus warneri bakteri türleri araştırmacılar tarafından izole edilerek tanımlanmıştır [20]. Başka bir çalışmada, ıslatma sıvılarında kullanılan \%12.5 didesil dimetil amonyum klorür ve $\% 12.5$ benzil dimetil amonyum klorür içeren kuarterner amonyum bileşiğinin Bacillus licheniformis, Bacillus pumilus, Staphylococcus intermedius, Pseudomonas luteola, Enterobacter cloacae, Vibrio fluvialis ve Enterococcus faecium bakteri türleri üzerine ve bu bakterilerin karışık kültür üzerine etkisi ayrı ayrı araştırılmıştır [6]. Bileşiğin $2.97 \mathrm{~g} / 1$ konsantrasyonu 8 ve 24 saatlik uygulama sürelerinde, $25^{\circ} \mathrm{C}$ ve $37^{\circ} \mathrm{C}$ sıcaklıkta test bakterilerini ve bunların karışık kültürünü tamamen inhibe ettiği bildirilmiştir [6]. Başka bir çalışmada, aktif içeriği sodyum dimetilditiyokarbamat olan antimikrobiyal maddenin minimum inhibisyon konsantrasyonu hem Chromohalobacter israelensis, Chromohalobacter canadensis, Halomonas halodenitrificans, Staphylococcus nepalensis, Halomonas halmophila $11 \mathrm{ml}$ halofil bakteri izolatları üzerine hem de bu izolatların karışı kültürü üzerine araştırılmıştır [7]. Bu antimikrobiyal maddenin minimum inhibisyon konsantrasyon değerinin Chromohalobacter israelensis, Chromohalobacter canadensis, Halomonas halodenitrificans, Halomonas halmophila ve test bakterilerinin karış1k kültürü için $15.6 \mu \mathrm{g} / \mathrm{ml}$ ve Staphylococcus nepalensis (KT1) için $0.96 \mu \mathrm{g} / \mathrm{ml}$ olarak bulunduğu araştırmacılar tarafından bildirilmiştir [7]. Islatma 
işleminden alınan sığır ve koyun derisi örneklerinde Enterobacteriaceae familyasına ait bakteri türleri saptanmıştır [8]. Sı ̆̆ır derilerinden izole edilen bakteri türlerinin Citrobacter freundii, Citrobacter koseri, Cronobacter sakazakii, Enterobacter amnigenus, Enterobacter cloacae, Kluyvera intermedia, Morganella morganii, Proteus mirabilis, Providencia rettgerii türlerini ıslatılmış koyun derilerinden, Citrobacter koseri, Cronobacter sakazakii, Ewingella americana, Kluyvera intermedia, Morganella morganii, Providencia rettgerii, Serratia marcescens, Serratia plymuthica ve Serratia rubidae olduğu bildirilmiştir [8].

Bu çalışmada, Staphylococcus epidermidis ATCC12228, Enterococcus faecalis ATCC29212 ve Bacillus subtilis ATCC6633 suşlarının kontrol altına alınabilmesi için gerekli olan test antimikrobiyalinin konsantrasyon değeri, $P$ seudomonas aeruginosa ATCC27853, Staphylococcus aureus ATCC29213, Micrococcus luteus ATCC9341 ve tüm test bakterilerinin karışık kültürünün kontrol altına alınabilmesi için gerekli olan konsantrasyon değerinden düşük bulunmuştur. Pseudomonas aeruginosa ATCC27853, Staphylococcus epidermidis ATCC12228, Staphylococcus aureus ATCC29213, Micrococcus luteus ATCC9341, Enterococcus faecalis ATCC29212, Escherichia coli ATCC25922, Bacillus cereus ATCC11778, Bacillus subtilis ATCC6633 suşlarının üzerine ve bunların karışık kültürü üzerine aktif içeriği sodyum dimetilditiyokarbamat olan antimikrobiyal maddenin minimum inhibisyon konsantrasyonunun araştırıldığı bir çalışmaya rastlanmamıştır. Sonuç olarak, ıslatma işleminde etkili antimikrobiyal maddelerin uygun konsantrasyonda kullanımı, bu işlenti basamağında bulunan antibiyotiklere dirençli bakterilerin gelişiminin önlenmesi ve yüksek kaliteli deri üretimi açısından oldukça önem taşımaktadır.

\section{KAYNAKLAR}

[1] Haines, M.B. (1984). Quality Rawstock. Journal of The American Leather Chemists Association, 4, 164-173.

[2] Bailey, D.G. \& Birbir, M. (1993). A Study of the Extremely Halophilic Microorganisms Found on Commercially Brine-cured Cattle Hides. Journal of The American Leather Chemists Association, 88, 285-293.

[3] Birbir, M. (1991). Deri Endüstrisinde Kullanılan İşlenmiş ve İşlenmemiş Sığır Derilerinde Derinin Kalitesine Etki Eden Mikroorganizmaların İzolasyonu ve İdentifikasyonu. Doktora Tezi, Marmara Üniversitesi Fen Bilimleri Enstitüsü, İstanbul, Türkiye.

[4] Adminis, U. \& Money, C.A. (2003). Short-term Preservation of Hides and Skins. Leather International, 26.

[5] Berber, D., Birbir, M., \& Hacıoğlu, H. (2010). Efficacy Assesment of Bactericide Containing Didecyldimethylammonium Chloride on Bacteria Found in Soak Liquor at Different
Exposure Times. Journal of The American Leather Chemists Association, 11, 354-359.

[6] Veyselova, C., Birbir, M., \& Berber, D. (2013). Minimal Bactericidal Concentration for a Quaternary Ammonium Compound Used in Soak Liquors. Journal of the Society of Leather Technologists and Chemists, 4(97), 166-171.

[7] Birbir, M., Ventosa, A., \& Caglayan, P. (2015). Characterization of Moderately Halophilic Bacteria found on the Sheep and Goat Skins. The Scientific Research Project Commission of Marmara University, Project number FEN-CDRP-040712-0281.

[8] Birbir, M. \& Yazıc1, E. (2016). Isolation and Identification of Bacterial Species Belonging to Family Enterobacteriaceae on Soaked Hide and Skin Samples and Determination of Their Antibiotic Susceptibilities to Different Antibiotics. The Scientific Research Project Commission of Marmara University, Project number FEN-C-YLP-041213-0456.

[9] WHO Critically Important Antimicrobials for Human Medicine. (2016). 5th revision, 1-48.

[10] Kacaniova, M. \& Juhaniakova, L. (2011). Microorganisms in Confectionary Products. The Journal of Microbiology, Biotechnology and Food Sciences, 1, 57-69.

[11] Birbir, M. \& Ilgaz, A. (1996). Isolation and Identification of Bacteria Adversely Affecting Hide and Leather Quality. Journal of the Society of Leather Technologists and Chemists, 80, 147-153.

[12] Serhan, M., Cailliez-Grimal, C., Borges, F., Revol-Junelles, A.M., Hosri, C., \& Fanni, J. (2009). Bacterial diversity of Darfiyeh, a Lebanese Artisanal Raw Goat's Milk Cheese. Food Microbiology, 26(6), 645-652.

[13] Mork, T., Kvitle, B., Mathisen, T., \& Jorgensen, H.J. (2010). Bacteriological and Molecular Investigations of Staphylococcus aureus in Dairy Goats. Veterinary Microbiology, 141, 134-141.

[14] Aslan, E. \& Birbir, M. (2011). Examination of Gram-positive Bacteria on Salt-pack Cured Hides. Journal of The American Leather Chemists Association, 106, 372-380.

[15] Aslan, E. \& Birbir, M. (2012). Examination of Gram-negative Bacteria on Salt-pack Cured Hides. Journal of The American Leather Chemists Association, 107, 106-115.

[16] Ulusoy, K. \& Birbir, M. (2015). Identification and metabolic activities of Bacterial Species Belonging to the Enterobacteriaceae on Salted Cattle Hides and Sheep Skins. Journal of The American Leather Chemists Association, 110, 86-199.

[17] Yazici, E. \& Birbir, M. (2018). Examination of Catabolic Activities of Enterobacteriaceae Isolated from Soaked Sheep Skins and Cattle Hides. Journal of the Society of Leather Technologists and Chemists, 102, 130-136.

[18] Newton, K.G., Harrision, J.C.L., \& Smith, K.M. (1977). Coliforms from Hides and Meat. Applied and Environmental Microbiology, 33, 199-200.

[19] Antic, D., Blagojevic, B., Ducic, M., Nastasijevic, I., Mitrovic, R., \& Buncic, S. (2010). Distribution of Microflora on 
Cattle Hides and its Transmission to Meat via Direct Contact. Food Control, 21, 1025-1029.

[20] Berber, D. \& Birbir, M. (2010). Examination of Bacterial Populations in Salt, Salted Hides, Soaked Hides and Soak Liquors. Journal of The American Leather Chemists Association, 105, 320-326.

[21] Akpolat, C., Ventosa, A., Birbir, M., Sánchez-Porro, C., \& Caglayan, P. (2015). Molecular Identification of Moderately Halophilic Bacteria and Extremely Halophilic Archaea Isolated from Salted Sheep Skins Containing Red and Yellow Discoloratios. Journal of The American Leather Chemists Association, 110, 211-220.

[22] Caglayan, P., Birbir, M., Ventosa, A., \& Sánchez-Porro, C. (2015). Characterization of Moderately Halophilic Bacteria from the Salt-pack Cured Hides. Journal of the Society of Leather Technologists and Chemists, 5, 250-254.

[23] Bauer, A.W., Kirby, W.M.M., Sherris, J.C., \& Turck, M. (1966). Antibiotic Susceptibility Testing by a Standardized Single Disk Method. American Journal of Clinical Pathology, 45, 493-496.

[24] CLSI (Clinical and Laboratory Standards Institute); Performance Standards for Antimicrobial Susceptibility Testing. 28th ed. CLSI supplement M100. Wayne, PA, 2018.

[25] EUCAST (The European Committee on Antimicrobial Susceptibility Testing); Breakpoint Tables for Interpretation of MICs and Zone Diameters, Version 8.1, 2018.

[26] Bilgehan, H. (2004). Clinical Microbial Identification, Barış Yayınları, Ankara, Türkiye.

[27] EUCAST, European Committee for Antimicrobial Susceptibility Testing of the European Society of Clinical Microbiology and Infectious Diseases (ESCMID) (2000). Determination of minimum inhibitory concentrations (MICs) of antibacterial agents by agar dilution, EUCAST Definitive Document E. Def 3.1, Clinical Microbiology and Infection, 6, 509-515.

[28] Wiegand, I., Hilpert, K., \& Hancock, R.E.W. (2008). Agar and Broth Dilution Methods to Determine the Minimal Inhibitory Concentration (MIC) of Antimicrobial Substances. $\mathrm{Na}$ ture Protocols, 3, 163-175.

[29] Hammer, K.A., Carson, C.F., \& Riley, T.V. (1999). Antimicrobial Activity of Essential Oils and Other Plant Extracts. Journal of Applied Microbiology 86: 985-990.

[30] Pfleiderer, E. \& Reiner, R. (1988). Microorganisms in Processing of Leather in Biotechnology.

[31] Yapıc1, A.N. \& Yapıcı, B.M. (2002). Deri İşletmelerinde Karşılaşılan Mikrobiyal Olaylar ve Kullanılan Mikrobisidler. Teknik Bülten, 34.

[32] Rangarajan, R., Didato, T.D., \& Bryant, S. (2003). Measurement of Bacterial Populations in Typical Tannery Soak Solutions by Traditional and New Approaches. Journal of The American Leather Chemists Association, 98, 477-485.

[33] Orlita, A. (2004). Microbial Biodeterioration of Leather and Its Control: A Review. International Biodeterioration and Biodegradation, 53, 157-163.

[34] Yapıc1, B.M., Yapıc1, A.N., Karaboz, İ., \& Tozan, M. (2004). Deri Sektöründe Kullanılan Bazı Bakterisitlerin Etkinliğinin Tespiti Üzerine Bir Araştırma. I. Ulusal Deri Sempozyumu, İzmir, 7-8 Ekim.

[35] Bilgi, S.T., Yapici, B.M., \& Yapici, A.N. (2009). Determination of Bacterial and Fungal Numbers in Floats of Pre-tanning Operations. African Journal of Biotechnology, 8, 1602-1607. 